DEUİFD LII / 2020, ss. 131-161.

\title{
MUSA KÂZIM BEY'IN (TAŞOZ MUTASARRIFI) KALEMİNDEN BİR OSMANLI ADASI: TAŞOZ
}

Habibe KAZANCIOĞLU ${ }^{\bullet}$

\section{ÖZ}

Ege adalar1 15. yüzyıldan itibaren Anadolu kıylarına yakın olanlarının fethiyle Osmanlı hakimiyetine girmeye başlamıştr. Kuzeydoğu Ege Adaları içinde yer alan ve Ege Denizi'nin en kuzeyinde yer alan Taşoz adası, karaya bağlantısının yakınlığı başta olmak üzere pek çok açıdan stratejik öneme sahiptir.

II. Meşrûtiyet dönemi ilim insanlarından ve idarecilerinden tarihçi, coğrafyacı, eğitimci ve idareci kimliği ile bilinen Musa Kâzım Bey, tarih ve coğrafyaya dair çok sayıda kitap ve makale yazmıstır. Bunlardan biri de 1913 yllında Tarih-i Osmanî Encümeni Mecmuası'nda yayımlanan Tassoz Tarihçesi isimli makalesidir. $\mathrm{Bu}$ makale Taşoz adasının hem genel tarihine hem de Musa Kâzım Bey'in mutasarrıflık vazifesiyle bizzat bulunduğu Taşoz’un o dönemdeki tarihine $1 s ̧ 1 k$ tutması bakımından oldukça önemli bir kaynaktır. Musa Kâzım Bey makalesinde Taşoz'un coğrafi, idari, siyasi ve iktisadi tarihi hakkında önemli bilgiler aktarmaktadır. Ayrıca bu makalede Taşoz'un 1672 tarihli bir kânunnâmesi ile Sultan II. Mahmud'un, Taşoz'u Mehmed Ali Paşa'ya ihsan ettiğini belgeleyen bir ferman (mülknâme) yer almaktadır.

Anahtar Kelimeler: Musa Kâzım Bey, Taşoz, Ege Adaları, II. Meşrûtiyet, Osmanl1 Devleti.

- Dr. Öğr. Üyesi, Trakya Üniversitesi, İlahiyat Fakültesi, İslam Tarihi Anabilim Dall, Asst. Prof. Dr., Trakya University, Faculty of Theology, Department of Islamic History Edirne / Turkey. habibekazanci@gmail.com, ORCID ID: https://orcid.org/ 0000-0003-4145-3607.

Makalenin Hakemlere Gönderiliş Tarihi : 03/09/2020

Makalenin Hakemlerden Geliş Tarihi : 05/11/2020 


\title{
AN OTTOMAN ISLAND FROM THE PEN OF MUSA KAZIM BEY (THASSOS GOVERNOR): THASSOS
}

\begin{abstract}
The Aegean islands began to come under Ottoman rule with the conquest of those close to the Anatolian coast from the 15th century. The island of Thassos, located in the Northeast Aegean 1slands and located in the far North of the Aegean Sea has strategic importance in many aspects, espeacially its proximity to land.

Musa Kâzım Bey, known as historian, geographer, educator and administrator, one of the scientists and administrators of the Second Constitutioan period, wrote many books and articles on history and geography. One of these articles is titled History of Thassos, puplished in the Journal of Tarib-i Osmani Encümeni in 1913.This article is a very important source in terms of shedding light on both the general history of the island of Thassos and the history of Thassos in that period, where Musa Kâzım Bey was personally as a governor. In his article, Musa Kâzım Bey provides important information about the geographical, administrative, political and economic history of Thassos. In addition, in this article, with a Kanunname of Thassos dated 1672 and there is a conveyance (mülknâme) documenting that Sultan Mahmud II bestowed Thassos on Mehmed Ali Pasha.
\end{abstract}

Keywords: Musa Kâzım Bey, Thassos, Aegean Islands, Second Constitutioan, Ottoman State.

\section{GİRİ̧̧}

Ege adaları, coğrafi ve uluslararası antlaşmalardaki konumları ile jeopolitik ve stratejik önemleri bakımından; Boğazönü Adaları, Saruhan Adaları, Menteşe Adaları, Kuzey Sporat Adaları, Kiklat Adaları olmak üzere beş gruptan oluşmaktadır. Taşoz adası, Çanakkale Boğazı'na ulaşan deniz yollarını kontrol etmesi bakımından önem arz eden Boğazönü Adaları (Semadirek, Gökçeada, Bozcaada, Limni Bozbaba) ile birlikte Trakya Adalar veya Kuzeydoğu Ege Adalar olarak da isimlendirilen adalar içinde yer alır. ${ }^{1}$

\footnotetext{
1 Nuri Karakaş, "Lozan Konferansı Görüşmelerinde Ege Adaları”, Ege Adalarmm Unutulan Halkı: Rodos ve Istanköy Türkleri, ed. Mustafa Kaymakç1, Cihan Özgün (Konya: Eğitim Yayınevi, 2019), 235.
} 
Ege Denizi'nin kuzeyinde yer alan Taşoz adası günümüzde Yunanistan sinırları içinde yer almakta olup idari olarak Kavala'ya bağlıdır. $379 \mathrm{~km}^{2}$ lik bir yüz ölçüme sahip olan ada dağlık ve ormanlarla kaplıdır. Dairevî bir şekle sahip ada, doğudan batıya $22 \mathrm{~km}$, kuzeyden güneye 28 km'lik bir alanı kapsamakta olup kuzeyde en yakın kara parçası olan Kavala'ya 11 deniz mili uzaklıktadır. Adanın batı sahilleri Orfani körfezinden 38, doğu sahilleri Dedeağaç'tan 50 deniz mili uzaklıktadır. Kuzeydoğu sahilindeki Limenas (Osmanlılar zamanındaki adı Liman, Limanköy) ile Casaviti (Osmanlılar zamanındaki adı Kazavit) adanın doğal limanlarıdır. Ada, mermer yataklarının yanı sıra gümüş, çinko ve civa madenleri bakımından da zengindir. ${ }^{2}$

Taşoz adasının ilk yerleşimcileri Fenikelilerdir. MÖ 7. yüzyılda Paroslular, Fenikelileri adadan çıkarmışlardır. Denizcilikte ve ticarette gelişmiş olan Taşozlular, kurdukları güçlü donanmalarıyla MÖ 5. yüzyılda dışarıdan gelen saldırılara karşı direnebilmişlerse de yine bu yüzyılda Perslilerin adayı istila etmelerinin önüne geçememişlerdir. Med Savaşlarının sonucunda Perslilerin adada nüfusu kırılmış Taşoz adası MÖ 465'te Atina Konfederasyonu'na bağlanmıştır. Atina ve Sparta arasında el değisstiren ada Büyük İskender'in babası Phillipe zamanında Makedonya'nın, daha sonra Roma'nın hakimiyetine girmiş Roma'nın ikiye ayrılmasıyla Doğu Roma (Bizans)'nın sınırları içinde kalmıştır. Ada, 1204 yılında IV. Haçlı Seferi sırasında İstanbul'un işgaliyle birlikte Venediklilere bağlanmıştır. Daha sonra 1261'de Bizans hâkimiyetine giren ada 1453 yani İstanbul'un fethine kadar Bizans'in elinde kalmıştır. ${ }^{3}$

Taşoz adası 1457 yılında Has Yunus Bey tarafindan fethedilmiştir. Ada bu tarihten sonra Venedikliler tarafindan işgal edilmişse de 1479 y1lında Osmanlı-Venedik arasında imzalanan İstanbul Antlaşması'yla Taşoz'da yeniden Osmanlı idaresi kurulmuştur. Taşoz; Gökçeada, Bozcaada, Limni, Semadirek adalarıly birlikte Gelibolu Sancağı'na bağlanmıştır. 1534 yılında Cezâyir Bahr-i Sefìd Eyaleti'nin ${ }^{4}$

Süleyman Kuz1ltoprak, "Taşoz", Türkiye Diyanet Vakefi İslâm Ansiklopedisi (İstanbul: TDV Yayınları, 2011), 40/159.

3 Elif Erden, Yakın Dönem Tarihimizde Tassoz Adası (İstanbul: İstanbul Üniversitesi, Sosyal Bilimler Enstitüsü, Yüksek Lisans Tezi, 2004), 3.

4 Cezâyir-i Bahr-i Sefîd Eyâleti (Kaptanpaşa Eyaleti): 1533 yllında kurulan Cezayir beylerbeyliği, idari olarak Kuzey Afrika ve Ege adalarını içine almaktadır. 
kurulmasından sonra Gelibolu Sancaŭg'nın bu eyalete bağlanmasıyla dolaylı olarak Taşoz da idari olarak Cezâyir Bahr-i Sefîd Eyaleti'ne dâhil olmuştur. $^{5}$

Taşoz adası, 1519'da padişah hassı, 1535'te sancakbeyi hassı, 1569-1614 yılları arasında Kaptanpaşa hassıdır. ${ }^{6}$

Taşoz adası 1672 yılında Kitabhâne-i Hümâyûn Vakfı daha sonra Kaptanpaşa hassı olarak kayıtlara geçmiştir. Sultan I. Mahmud'un Taşoz'un gelirlerini Ayasofya Câmii'nin bitişiğinde inşa ettirdiği kütüphane ve imarete vakfetmesiyle, Taşoz adası 1740 y1linda Kaptanpaşa hassından ayrilarak Haremeyn Vakıfları idaresine dahil olmuştur. ${ }^{7}$ Daha sonra Haremeyn'e tâbi vakıf mukataaları diğer miri mukataalar gibi "mal ve kalemiye" takrir olunarak belirli bir bedel karşılığında mâlikâne olarak verilmiştir. ${ }^{8}$

Sultan II. Mahmud'un, Kavalalı Mehmed Ali Paşa'nın Kavala'da kuracağ1 külliyenin giderleri için Taşoz'un kendisine temlik edilmesi talebini kabul etmesi Taşoz tarihinde önemli bir dönüm noktası olmuştur. 1813-1902 yılları arasında, Taşoz adası Misır'dan gönderilen vakıf müdürleri tarafindan yönetilmiştir. Son dönemdeki vakıf müdürlerinin idaresinden rahatsız olan halk isyan etmiştir. Bunun üzerine Taşoz adasının temsilcileri Bâbıali'nin müdahalesini istemek üzere Kavala'ya gitmişlerdir. Selanik Valisi Osmanlı Devleti'nin hem adadaki yönetim hakkını kullanmak hem de adada asayişi sağlamak gayesiyle Kavala Kaymakamı Emin Paşa'yı askerleriyle birlikte adaya çıkarmıştır. 7 Mayıs 1902'de Taşoz'un yönetimi Mısır Vakıf idaresinden alınarak

Kurulduğu yüzyılda Gelibolu, Eğriboz, Karlı-ili, İnebahtı, Midilli, Sakız ve Cezayir-i Mağrib olmak üzere 7 idari birimden oluşan bu eyaletin birimlerinde daha sonraki yüzyıllarda değişiklikler olmuştur. 1908 yılında Rodos, Midilli, Sakız ve Limni'yi içine alan Cezâyir-i Bahr-i Sefîd Eyâleti, Balkan Savaşları ve I. Dünya Savaşı sonrasında dağılmıştır. Mahmut H. Şakiroğlu, "Cezâyir-i Bahr-i Sefîd ”, Türkiye Diyanet Vakefi İslâm Ansiklopedisi (İstanbul: TDV Yayınları, 2011), 7 /500-501.

5 Ali Arslan, Balkeanlarn Anabtar Önemi Bilinmeyen Ada: Taşör (İstanbul: Emre Yayınlan1, 2005), 13-14.

6 Yasemin Demircan, Osmanl İdaresinde Taşoz (Ankara: TDFO, 1996), 43-49.

7 Arslan, Balkanlarn Anabtar Önemi Bilinmeyen Ada: Tașöz, 14.

8 Erden, Yakın Dönem Taribimizde Tasoz, Adası, 8. 
doğrudan Selânik'e bağlanmıştır. Adanın sadece vakıf işlerinin yönetimi Mehmed Ali Paşa'nın vakfina bırakılmıştır. Sultan II. Abdülhamid Mısır vasitasiyla İngiltere'nin muhtemel baskisını ortadan kaldırma düşüncesiyle adaya 27 Mayis 1902'de sancak statüsü verip buraya bir mutasarrıf tayin etmiştir. ${ }^{9}$ H.1322 / M. 1904 tarihli Selanik Salnâmesi'nde Taşöz Sancağının Cezâyir Bahr-i Sefìd Eyaleti’ne bağlı olduğu bilgisi yer almaktadır. ${ }^{10}$

Güvenlik kaygısının ortadan kalkmasıyla ada önce birinci sınıf daha sonra üçüncü sınıf kazaya dönüştürülmüştür. I. Balkan Savaşının başlangıcında Yunanistan Taşoz'u Semadirek adasıyla birlikte işgal etmiş, vakıf binalarını kapatmış vakıf görevlilerini adadan çıkartmıştır. Osmanlı Devleti, vakfa ait malların özel mülk olduğunu belirterek Yunanistan'ın işgallerini protesto etmiş ve işgali tanımamıştır. Taşoz, Lozan Antlaşması'yla hukuken Türk egemenliğinden çıkmıştır. Vakfin son mütevellisi Mısır'ın son hidivi II. Abbas Hilmi'nin hukuki girişimlerinden de olumlu bir netice alınamamıştır. ${ }^{11}$

\section{Musa Kâzım Bey (Taşoz Mutasarrıfı 1902-1903)}

Musa Kâzım Bey, II. Meşrûtiyet döneminde yaşamış ilim insanlarındandır. Ancak aynı dönemde yaşamış olan Şeyhülislam Musa Kâzım Efendi ile isim benzerliğinden dolayı birbirleriyle karıştırılmışlardır. İsmet Parmaksızoğlu Türk Ansiklopedisi'ndeki "Musa Kâzım Efendi" maddesinde "Musa Kâzım Bey" in eserlerini "Şeyhülislam Musa Kâzım Efendi" nin eserleri arasında nakletmiştir. ${ }^{12} \mathrm{Bu}$ hatalı bilgi sonraki bir kısım araştırmacılar tarafından devam ettirilmiştir.

Ahmet Şamil Gürer, "Gelenekle Modernite Arasında Bir Meşrûtiyet Şeyhülislâmı: Musa Kâzım Efendi (1861-1920)” isimli doktora tezinde Musa Kâzım Bey'in Musa Kâzım Efendi'den ayrı bir müellif

\footnotetext{
9 Kiziltoprak, “Taşoz”, 160.

10 Selânik Vilâyeti Sâlnâmesi (1322), (Selanik: Hamidiye Mekteb-i Sanayi Matbaası), 486.

11 Kiziltoprak, "Taşoz", 160.

12 İsmet Parmaksızoğlu, "Mûsa Kâzım Efendi", Türk Ansiklopedisi (Ankara: Milli Eğitim Basımevi, 1976), 24/457-458.
} 
olduğuna dikkat çekmiştir. ${ }^{13}$ Son olarak Nebahat Göçeri'nin "Kozan Mutasarrıf-1 Esbakı Musa Kâzım'ın Kitapları-I” ile "Kozan Mutasarrıf-1 Esbakı Musa Kâzım'ın Makaleleri-II” isimli makaleleriyle Musa Kâzım Bey'in kimliği hakkında netlik sağlanmıştır. ${ }^{14}$

Musa Kâzım Bey, Sultan II. Abdülhamid dönemi aydınlarından olup uzun süre öğretmenlik, müdürlük, maarif müdürlüğü, maarif müfettişliği gibi eğitim-öğretim hizmetlerinde bulunmuştur. Musa Kâzım Bey, 1887 yllında Galatasaray Lisesi'ni bitirmiştir. Kastamonu İdâdîsi’nde öğretmenlik yapan Musa Kâzım Bey daha sonra Ankara İdâdîsi'nde müdürlüğün yanı sıra Fransızca muallimliği, Ankara Darülmuallimin'de de meslek dersleri öğretmenliği yapmıştır. ${ }^{15}$

Osmanlı arşiv belgelerinden elde ettiğimiz bilgilere göre Musa Kâzım Bey H.1310-1312 y1lları arasında Ankara İdâdîsi Müdürlüğünü yürütmektedir. ${ }^{16}$ H.1313 / M. 1895 yllında Ankara İdâdî Müdürlüğünden Adana Maarif Müdürlügüne tayin olmuştur. ${ }^{17} 8$ Muharrem 1314 (18 Haziran 1896) tarihli bir belge Musa Kâzım Efendi'nin Adana Maarif Müdürlügünden Ankara Maarif Müdürlügüne tayin edildiğini haber vermektedir. $^{18}$

13 Ahmet Şamil Gürer, Gelenekle Modernite Arasında Bir Meşrûtiyet Şeybülislâm: Musa Kâzım Efendi (1861-1920) (Ankara: Hacettepe Üniversitesi, Sosyal Bilimler Enstitüsü, Doktora Tezi, 2003), XV.

14 Nebahat Göçeri, “Kozan Mutasarnıf-1 Esbakı Musa Kazım’ın Kitapları-I”, Cukurova Üniversitesi Türkoloji Dergisi 3/2 (Aralık 2018), 95-119; Nebahat Göçeri, "Kozan Mutasarrıf-1 Esbakı Musa Kazım'ın Makaleleri-II”, Cukurova Üniversitesi Türkoloji Dergisi 3/2 (Aralık 2018), 120-130.

15 Cavit Binbaşıŏlu, Başlangıstan Günümüze Türk Eğitim Taribi (Ankara: Anı Yayınlan1, 2009), 232.

16 Osmanlı Arşivi (BOA), Maarif Nezareti-Mektubi Kalemi [MF. (MKT)], No. 189, Gömlek No.42; Osmanlı Arşivi (BOA), Maarif Nezareti-Mektubi Kalemi [MF. (MKT)], No. 244, Gömlek No. 18.

17 Osmanlı Arşivi (BOA), Maarif Nezareti-Mektubi Kalemi [MF. (MKT)], No. 330, Gömlek No.42; Osmanlı Arşivi (BOA), Maarif Nezareti-Mektubi Kalemi [MF. (MKT)], No. 296, Gömlek No.46.

18 Osmanlı Arşivi (BOA), Maarif Nezareti-Mektubi Kalemi [MF. (MKT)], No. 321, Gömlek No.8. 
Musa Kâzım Bey'in, Tanzimat'la başlayan eğitimdeki Usûl-i Cedîd hareketi kapsamında gerçekleştirilen faaliyetlere önemli katkıları olmuştur. Muallim Cevdet’in ifadelerinde de geçtiği üzere Musa Kâzım Bey, pedagoji sahasına ilgi gösteren dönemin az sayıdaki eğitimcilerindendir. ${ }^{19}$ Musa Kâzım Bey, Ankara İdâdîsi'nde müdür ve Darülmuallimîn'de öğretmen olarak görev yaparken birinci cildi H.1310 / M. 1894'te ikinci cildi H.1313 / M.1897'de yayınlanan Rehber-i Tedris ve Terbiye isimli iki ciltlik bir eser kaleme almıştır. ${ }^{20}$ Öğretmenlere rehberlik amaciyla yazılan bu kitap ilk pedagoji kitaplarından olarak kabul edilmektedir. Öğretmenlik mesleği, genel öğretim yöntemleri, eğitim bilimleri ve eğitim tarihi hakkında bilgilerin yer aldığı bu eser Musa Kâzım Bey'in döneminin pedagojik formasyon anlayışını ortaya koyması bakımından önem arz etmektedir. ${ }^{21}$ Musa Kâzım Bey'in II. Meşrûtiyet döneminde öğretmen okullarında okutulan bir de "Hükema-i Cihan ve Tâlim ve Terbiye Tarihi” isimli bir pedagoji kitabı bulunmaktadır. ${ }^{22}$

Arşiv belgeleri Musa Kâzım Bey'in Ankara İdâdîsi müdürlüğü sırasında kaleme aldığ iki eserden daha haber vermektedir. Bunlardan ilki Kadinlara Mabsus Talim ve Terbiye Rebberi isimli kitab ${ }^{23}$ diğeri ise Almanya ve Amerika'nın talim ve terbiyesi hakkında yazdığı kitabıdır. ${ }^{24}$

Musa Kâzım Bey her ne kadar eğitimci kimliği ile biliniyorsa da kaleme aldığı kitaplar ve makaleler onun daha ziyade tarih ve coğrafyayla ilgilenen bir ilim insanı olduğuna işaret etmektedir. Nitekim Musa Kâzım Bey tarih ve coğrafyayla ilgili, Mubtasar Coğrafya-yı Osmanî (1304 / 1888),

19 Yahya Akyüz, Türk Eğitim Taribi (İstanbul: İstanbul Kültür Üniversitesi Yayınlar1, 1997), 160.

20 Akyüz, Türk Ë̆itim Taribi,185.

21 Mustafa Şanal, "Musa Kâzım Bey'in (1858-1919) Türk Eğitim Tarihindeki Yeri ve Öğretmenlik Mesleğine İlişkin Görüşleri”, Turkish Studies 5/3 (Summer 2010), 1877.

22 Cavit Binbaşıŏ̆lu, 'Türkiye'de Eğitim Bilimleri Tarihi Araştırmaları: II. Meşrutiyet Döneminden Harf Devrimine Kadar Öğretmen Okullarında Okutulan Eğitim Bilimine İlişkin Kitaplar”, G.Ü. Gaæi Eğitim Fakültesi Dergisi 16 /2 (1996), 108-109.

23 Osmanlı Arşivi (BOA), Maarif Nezareti-Mektubi Kalemi [MF. (MKT)], No. 244, Gömlek No.18.

24 Osmanlı Arşivi (BOA), Maarif Nezareti-Mektubi Kalemi [MF. (MKT)], No. 330, Gömlek No. 42. 
Mubit-i İdare ve Siyâsiyyat (1325 / 1909), Mubttra-i Ricâl u Siyâsiyyûn (1326 / 1910), İcmâl-i Tevârib-i Cihân (1327 / 1911), Devr-i İstibdâd Abvâli ve Müsebbibleri (1327 / 1911) isimli kitaplar ${ }^{25}$ ile Tarih-i Osmanî Encümeni'nde yayımlanan, Vesaik-i Taribiyyemiz. (1326 / 1910), Darbhane'nin Abval-i Dabiliyyesi (1327 / 1911), Aynaroz Taribçesi (1329 / 1913), Tașoz Tarihçesi (1329 / 1913), Memalik-i Osmaniyyye'deki Müessesat-ı Merhebiyye Hakkinda Malumat-ı Mubtasara (1329 / 1913), Abtimar Katogikosluğu (1330 / 1914) isimli makaleler kaleme almıştır. ${ }^{26}$

Musa Kâzım Bey'in eğitimci ve tarihçiliğinin yanında bir de idareci kimliği dikkat çekmektedir. Osmanlı arşiv belgelerinde geçen bilgilere göre Musa Kâzım Bey ülkenin farklı bölgelerinde mutasarrfflı ${ }^{27}$ görevinde bulunmuştur.

24 Rebiülevvel 1320 (1 Temmuz 1902) tarihli bir belgede Musa Kâzım Bey'den Muş eski mutasarrıfı olarak söz edilmektedir. Aynı belgeden Musa Kâzım Bey'in bu tarihte Kosova ve Manastır Vilayetleri Maarif Müfettişliği vazifesinde olduğu anlaşılmaktadır. ${ }^{28} 27$ Rebiülevvel 1320 (4 Temmuz 1902) tarihli irade Musa Kâzım Bey’in Taşöz Sancağ1 Mutasarrıflığına tayin edildiğini haber vermektedir. ${ }^{29}$ Musa Kâzım Bey Taşoz mutasarrıflığını bir seneye yakın süre yürütmüştür. Nitekim Ferit

25 öçeri, “Kozan Mutasarrıf-1 Esbakı Musa Kazım’ın Kitaplar1-I”, 95-119.

26 Halil Edhem, Fihrist-i Umumi (İstanbul: Devlet Matbaası, 1928), 33; Göçeri, "Kozan Mutasarrıf-1 Esbakı Musa Kazım'ın Makaleleri-II, 120-130.

27 Mutasarrıf: Osmanlı idari teşkilatında sancak veya liva denilen idarenin başındaki yöneticiye verilen unvan. Mehmet Zeki Pakalın, Osmanl Tarih Deyimleri ve Terimleri Sözlïğ̈̈ (İstanbul: Milli Eğitim Bakanlı̆̆1 Yayınları,1993), "Mutasarrıf” 2/586.

28 Osmanlı Arșivi (BOA), Dabiliye- Mektubi Kalemi [D.(MKT)], No. 532, Gömlek No. 20.

29 Taşoz ceziresinde mutasarrıflık teşkili emr u ferman-1 hümâyûn cenâb-1 mülûkâne iktizâ-yı âlişandan olunacağı mutasarrıflı̆̆a vukûfu ve iktidârı cihetiyle Kavala ve Manastır vilayetleri teftiş heyetinden Musa Kâzım Efendi'nin tayini hususuna dâir Memurîn-i Mülkiye Komisyonu'nun mazbatası Dâhiliye Nezâret-i Celîlesi'nin tezkiresi ve terceme-i hâli ve rakabesi ile bir bab arz ve takdim kılınmış olmağla ol babda irâde-i seniyye-i hilâfetpenâhi müteallik ve şerefsudûr buyrulur ise mantûk-1 münîfinin iktizâ eyleyeceği beyaniyle tezkîre-i senâveri terkîm olundu efendim. Sadrazam Rifat (27 Rebiülevvel 1320/ 20 Haziran 1318) (Osmanlı Arşivi (BOA), Yuldı-Maruzat Defterleri [Y.(MRZ)], No.10475. 
Paşa'nın 11 Safer 1321 / 26 Nisan 1903 tarihli iradesinde Musa Kâzım Bey'in memuriyete mugayir hareketlerinden dolayı Taşoz mutasarrıflı̆̆ından alınıp yerine Maraş mutasarrıfı Arifi Paşa'nın tayin edildiği bildirilmektedir. ${ }^{30}$

21 Zilhicce 1321 (9 Mart 1904) tarihli belgeden Musa Kâzım Efendi Taşöz Mutasarrıflığından Ertuğrul Mutasarrıfllğına atandığı anlaşılmaktadır. $^{31} 11$ Zilkade 1324 (27 Aralık 1906) tarihli belgede Ertuğrul Sancağı Mutasarrıfı olan Musa Kâzım Efendi’nin Draç Sancağı Mutasarrıfı Ziya Bey ile becayiş yaptığını bildirmektedir. ${ }^{32}$ Musa Kâzım Efendi Dıraç Mutasarrıflı̆̆ından sonra H.1324-1325 / M.1907-1908 Kozan Mutasarrıfllğına atanmıştır. ${ }^{33} 14$ Rebiülevvel 1327 (5 Nisan 1909) tarihli belge Musa Kâzım Efendi'nin Kozan Mutasarrıflı̆̆ından azledildiğini haber vermektedir. ${ }^{34}$

Tarih-i Osmani Encümeni, 14 Teşrîn-i Sânî 1325 (27 Kasım 1909) tarihinde padişah Mehmed Reşad'ın iradesiyle Vak'anüvis Abdurrahman Şeref Bey'in başkanlığında kurulmuş resmi bir teşkilattır. Teşkilatın gayesi devrin siyasi anlayışı doğrultusunda halka milli şuurun yanında tarih bilgisi ve şuuru kazandırmaktır. Tarih-i Osmani Encümeni'nin en önemli faaliyetlerinden biri daha sonra adı Türk Tarih Encümeni olarak değiştirilen Tarih-i Osmanî Mecmuası'nı (TOEM) neşretmesidir. $\mathrm{Bu}$ mecmuanın çıkış sebebi Encümen'in neşretmeyi düşündüğü Osmanlı tarihine malzeme hazırlamaktı. 1 Nisan 1326 (1910) tarihinde yayımlanmaya başlayan dergi kesintisiz sekiz yıl yayımlandı. Mondros Mütarekesi sebebiyle kesintiye uğrayan derginin yayını

30 Osmanlı Arşivi (BOA), Yıldı- Resmi Maruz̧at Defterleri [Y.(RES)], No.120, Gömlek No.94.

31 Osmanlı Arşivi (BOA), BOA. Osmanlı Arşivi. Dabiliye-Mektubi Kalemi [D.(MKT)]. No. 2606, Gömlek No.137. Musa Kâzım Bey, Ertuğrul Sancağ1 (Günümüzde Bilecik İli) Mutasarrıflı̆̆ sırasında burada İznik Saat Kulesi’ni inşa ettirmiştir. http://www.izmit.gov.tr/izmit-saat-kulesi

32 Osmanlı Arşivi (BOA), Bab-ı Ali Evrak Odası [BEO.]. No. 2969, Gömlek No. 222647.

33 Osmanlı Arşivi (BOA), Dabiliye-Mektubi Kalemi [D.(MKT)]. No.1182, Gömlek No.60; Yildz-Hususi Maruzat Defterleri [Y.(HUS.)]. No.514, Gömlek No.105.

34 Osmanlı Arşivi (BOA), Dabiliye-Mektubi Kalemi [D. (MKT)], No. 2786, Gömlek No.16. 
dokuzuncu ve onuncu seneler 1921 y1linda bir fasikül olarak, on bir, on iki ve on üçüncü yıllar 1923 yllında yine bir fasikül olarak yayımlanmıştır. Cumhuriyet döneminde adı "Türk Tarih Encümeni Mecmuası (TTEM)" olarak değişen derginin devam etmekte olan yetmiş sekizinci sayısı yeni derginin birinci sayısı olarak kabul edilmiş derginin bu şekildeki ikinci yayım dönemi Encümen'in dağılması sebebiyle ancak üç yıl sürmüştür. ${ }^{35}$

Tarih-i Osmani Encümeni, Abdurrahman Şeref Efendi başkanlığında 11 daimî aza ile 20 muâvin (yardımc1) azalardan oluşmaktadır. Musa Kâzım Bey, Tarih-i Osmanî Encümeni’nin yardımcı üyeleri arasında yer almakta olup "Kozan Mutasarrıf-1 Esbâkı" unvanı ile kayıtlıdır. ${ }^{36}$

\section{Taşoz Tarihçesi}

Musa Kâzım Bey’in “Taşoz Tarihçesi” başlıklı makalesi, Abvâl-i Coğrafya, Ahvâl-i Kadîme, Taşoz'un Mistrhlar Devri isimli üç bölüm, Taşoz'un 17. Yüzyıla ait bir Kanunnâmesi ile Sultan II. Mahmud'un Taşoz’u Kavalalı Mehmed Ali Paşa'ya temlîk ettiğini konu alan bir fermanından oluşmaktadır.

\subsection{Taşoz'un Coğrafî Durumu}

Musa Kâzım Bey makalesinde Abvâl-i Coğrafya başlı̆̆1 ile ele aldığ1 bu bölümde Taşoz'un coğrafî durumuyla ilgili olarak şu bilgileri aktarmaktadır: Adanın çevresi on sekiz çapı yedi, Kavala ile arasındaki boğazın uzaklığ1 ise dört fersab ${ }^{37}$ tır. Musa Kâzım Bey, zeytin ve çam ormanlarıla kaplı olan adanın zemininin mermer tabakalardan oluştuğunu belirtip adanın her yerinde mermerden yapılmış bir lahit veya bir kabirle karşılaşılabileceğini haber vermektedir.

Makalede geçen bilgilere göre Liman İskelesi civarında güzel bir şelale vardır. Fenikelilerin buradan değerli taşlar ihraç ettikleri rivayet

35 Abdülkadir Özcan, "Târih-i Osmânî Encümeni”, Türkiye Diyanet Vakefi İslâm Ansiklopedisi (İstanbul: TDV Yayınlar1, 2011), 40 /84-85.

36 Tarih-i Osmanî Encümeni Mecmuası, "Tarih-i Osmanî Encümeni Hakkında Talimat Sureti”, $1 / 1$ (1 Nisan 1326), 8.

371 fersah=7500 arşun $=5685$ metredir. Halil İnalc1k, Osmank Imparatorluğu Klâsike Çăg( 1300-1600) (İstanbul: Yap1 Kredi Yayınlar1, 2004), 249. 
edilmektedir. Ormanların içinde harap yani bakımsız hale gelmiş bağlar vardır. Taşoz şarabının eski şöhreti bu bağlardan geliyor olmalıdır. Taşoz'u başlangıçta işgal eden ve oraya yerleşenler Fenikelilerdir. Bunlar Melikeret mezhebini yaymaya ve nüfuslarını yaymaya çalışmışlardır. Taşoz, Fenikeli bir adamın ismidir. İlk çağlarda adanın kuzey doğusunda Taşoz adıyla anılan yirmi bin nüfuslu bir kasaba bulunmaktaydı.

Makalenin kaleme alındığı zamanda adada on üç köy vardır ve adanın nüfusu yirmi bin kişiden oluşmaktadır. Adada Müslüman ahali yoktur. Ancak bir dağ eteğinde cami ve minare harabesi görülmektedir. Adada yüksek ve göz alıcı Pisarion (İpsarion) ve Terepera adlı iki dağı vardır ki bu dağlardan Pisarion'a halk kutsiyet yüklemiştir. H. 1298 / M. 1880 yılında Panaya'dan Liman Karyesi'ne nakl ve kışın Kavala'ya göç etme âdeti resmen terk olunmuştur.

\section{Kadarki Tarihi}

\subsection{Taşoz'un Başlangıcından Osmanlılar Dönemine}

Musa Kâzım Bey, makalesinin Abvâl-i Kadîme olarak isimlendirdiği bu bölümünde ana hatlarıyla Taşoz'un MÖ 5. yüzyıldan Osmanlılar tarafından fethine kadarki tarihi üzerinde durmaktadır.

Taşoz adasının tarihini MÖ 5. yüzyıldan başlatan Musa Kâzım Bey, adanın tarihi ile ilgili şu bilgileri aktarmaktadır: Şair Arhilous İoanya'dan Taşoz'a ahali getirerek Fenikelileri adadan çıkarmıştır. ${ }^{38}$ MÖ 494'te Taşozlular bir ordu oluşturmuş ve adayı istilaya gelen Midillileri adadan uzaklaştırmada başarılı olmuşlardır. MÖ 490 yılında Pers komutanı Mardiniyus Taşoz'a girmiş, ada sakinlerinin donanmasını dağıtmış ve müstahkem surlarını yıktırmıştır. Pers Kralı I. Serhas, ordusunu bir hafta boyunca ada halkına besletmiş böylece ada halkını 400 talan $^{39}$ lik masrafa sokmuştur. Taşozlular İranlıların (Persliler) nüfuzundan kurtulmak için y1llık altı talan vergi vermek şartıyla Atina'ya tâbi olmuşlardır. Tabi oldukları süre içinde iki defa isyan ettilerse de General

38 Denizcilikle uğraşan Paroslular, milâttan önce VII. yüzyılda Taşoz'da (Thasos) Biga dolaylarındaki Parium'da ve Adriyatik'te Hvar (Lesina) adasinda koloniler kurmuşlardi. Feridun Emecen, "Para". Türkiye Diyanet Vakfi İslâm Ansiklopedisi (İstanbul: TDV Yayınları, 2007). 34 / 166.

39 Bir talan beş bin küsur dırahmi ve bir drahmi yüz paradır. (Müellif Musa Kâzım Bey'in açıllaması) 
Kimon ve Trazbul isyanı bastırmıştır. Isparta, Makedonya ve Roma idarelerinde Taşoz'un imarına ve ilerleyişine önem verilmiştir. Taşoz, Bizans döneminde korsanların sığınağı haline gelmiş bu yüzden ada halk1 dağlara çekilmiş sahildeki köyler ve zeytinlikler harabeye dönmüştür. Yine Bizans döneminde Taşoz'un idaresi belediye ve nahiye şeklinde olmuştur. $\mathrm{Bu}$ idarenin başına melike ve münciye gibi unvanlarla anılan kadınlar bile geçmiştir. Musa Kâzım Bey kadın idarecilere ait mezar kapaklarında bu unvanların görüldüğünü ifade etmektedir. Orta Çağ'da, 904 yılında Taşoz, Selanik ile beraber Barbarların saldırılarına uğramıştır. ${ }^{40}$ Taşoz miladi altıncı asırda Halkidya, onuncu asırda Trakya Eyaletine bağlı iken on üçüncü asırda Cenevizlilerin eline geçmiştir. Musa Kâzım Bey, makalesini yazdığı zamanı kastederek "şimdiki kale ve hisarlar Ceneviz kumandanlarından Tiçonus'un yadigarıdır" demektedir. Miladi 1327 yılında Taşoz yeniden Bizans idaresine katılmış ve H.861 / M.1456 y1lında adanın bütün ahalisi İstanbul'a nakledilerek orada iskan olunmuştur.

Musa Kâzım Bey, Ahvâl-i Kadîme başlıklı bölümünün devamında "Selanik'e merbut olmak üzere miladın 1813 senesine müsadif 1228 senei hicriyesine kadar ada şu kanunnâme ile idare edildi" dedikten sonra Kânunnâme başlı̆̆ ile altında Defter Emini el-Hâc Hacı Mustafa'nın ismi bulunan Gurre-i Muharrem 1083 (29 Nisan 1672) tarihli Taşoz'a ait kânunnâmeyi vermektedir. Sultan IV. Mehmed (1648-1687) dönemine tekabül eden bu kânunnâmede ${ }^{41}$ şu hükümler yer almaktadır:

a) İpsala, Boz Baba ile birlikte Taşözü adalarında yaşayan zımmî reâyânın ispence ${ }^{42}$ leri yirmi beşer akçe olup bâliğ olmayanlardan ispence alınmamaktadır.

40904 yllı yazında Girit'ten gelen bir Arap donanması şehri ele geçirdi, on gün süren yağmanın ardından iddia edildiği üzere 22.000 esir alarak Girit'e döndü. Machiel Kiel, "Selânik", Türkiye Diyanet Vakfi İslâm Ansiklopedisi (İstanbul: TDV Yayınlanı, 2009), 36 / 352.

41 Sultan IV. Mehmed dönemine ait Taşözü Ceziresi'nin Kânunnâmesi için bkz. Ahmet Akgündüz, Osmanl Kanunnâmeleri ve Hukêkkî Tablilleri (İstanbul: Osmanlı Araştırmaları Vakfı Yayınları, 2015), 10 / 955.

42 İspence: Osmanlı'da bülûğa ermiş her gayr-i müslim reâyanın ödediği örfî̀ bir baş vergisidir. Bu vergiye sadece yerleşik köylüler değil göçebeler, şehir ve kasaba halk1 
Kânunnâmenin ilerleyen satırlarında "ispenceleri yüzer akçe alınırmış kırkar akçe alına" şeklinde bir ibare bulunmaktadır. Bu vergi miktarının Gurre-i Muharrem 1083 (29 Nisan 1672) tarihli kânunnâme ile ilgisi yoktur. $\mathrm{Bu}$ tarihte ispence miktarı yukarıda da belirtildiği gibi yirmi beşer akçedir. "ispenceleri yüzer akçe alınırmış kırkar akçe alına" hükmünü, İnalcık'in Osmanlılar'da Raiyyet Rüsûmu isimli makalesinde geçen 'Taşoz'un ispence vergisi 1519'da 25 akçe iken 17. asırda 100 akçeye çıkarılmış daha sonra 40 akçeye düşürülmüştür." ${ }^{33}$ bilgisiyle açıklamak mümkündür. Ayrıca kânunnâmede 40 akçe olan ispencenin 25 akçeye indirildiği anlaşılmaktadır.

b) Tarlalardaki męrûât (ekin), hadravât (sebze) ve bububât (buğday, arpa, çavdar vb. tahıllar) her ne ekili ise elde edilen mahsulün vergisi, harac-ı mukâseme ${ }^{44}$ usulüne göre hums (bește bir) miktarında alınmaktadır.

c) Şıralar1 (üzüm suyu / şarap) sahibinde kalmak üzere kryyye $e^{45}$ si için ikişer akçe resm-i şıra ${ }^{46}$ alınırdı. Engûr (üzüm) hassının dışındaki harâcî araziden bums miktarı vergi alınmaktadır.

ç) Resm-i otlak ve resm-i yaylak ${ }^{47}$ koyun başına ikişer akçedir. Kânunnâmenin düzenlendiği zamanda Şeriffi altınin rayici, ikişer ve rubu'

da tâbi idi. İspence, çift resmi gibi genellikle timara tahsis edilmekteydi. Halil İnalc1k, “Osmanlılar'da Raiyyet Rüsûmu”, Belleten 23/92 ( Ekim 1959), 603-604.

43 İnalcık, "Osmanlılar'da Raiyyet Rüsûmu”, 607.

44 Harac-1 Mukâseme: Müslümanlardan alınan öșür mukabili olarak zımmî reâyâdan alınan mahsül vergisidir. Onda birden iki de bire kadar alınan bu vergi, hiçbir zaman mahsülün yarısını geçemez, toprak ekilmediği zaman da alınmazdı. Eğer zımmî toprağını yılda iki kez ekerse bu vergiyi iki defa öderdi. Yavuz Ercan, "Osmanlı İmparatorluğu'nda Gayrimüslimlerin Ödedikleri Vergiler ve $\mathrm{Bu}$ Vergilerin Doğurduğu Sosyal Sonuçlar”, Belleten 55/ 213 (Ağustos 1991), 385.

45 Kıyye: Vukıyye, okıyye, kıyye veya okka olarak adlandırılan bir ağırlık ölçüsü.

46 Resm-i Şıra: Üzüm şırasından alınan bu verginin miktarı yer ve zamana göre değişiklik göstermekte olup alınma zamanı üzümlerin tekneye girip sıkılmaya başlama zamanıdır. Ziya Kazıcı, Osmanlilarda Vergi Sistemi (İstanbul: Şamil Yayınevi, 1977), 93.

47 Resm-i otlak (resm-i kışlak) ve resm-i yaylak: Sürülerini başka timar sahibi kimselerin arazisinde veya mîrî (devlete ait) kışlaklarda kışlatan ve yaylaklarda yaylatan kimselerden alınan vergidir. Neşet Çağatay, "Osmanlı İmparatorluğu'nda Reayadan Alınan Vergi ve Resimler" Ankara Universitesi Dil ve Tarib-Cografya Fakültesi Dergisi $5 / 5$ (1947), 492; 509-510. 
esedî kuruştan işlem görmektedir. Bu vergi berelerinden ve nâmevcudundan alınmamaktadır.

d) Resm-i Küvvâre ${ }^{48}$ kovan başına ikişer akçe olup, mevcudundan alınır. Kânunnâmede, Taşözü adasında kadimden beri kovan başına onar akçe öşr alındığı ve bunun aynen devam ettirileceği kayıtlıdır.

e) Resm-i âsiyâb-ı âb ve bâd (su ve yel değirmeni) ve âsiyâb-ı revgân-ı zeyt (zeytin yağı değirmeni ) ${ }^{49}$ defterde belirlendiği miktarda alınır.

f) Manastırlarda çalışmaya gücü yeten, kar ve kazanç sağlayan rahiplerin cizyeleri ednâ (en düşük oran) hesabindan olmak üzere yüz doksan akçe olup kar ve kazanç sağlamaya gücü yetmeyecek şekilde yaşlı olanlardan cizye alınmamaktadır.

g) Resm-i gerdek $k^{50}$, olarak bâkire kızdan altmış, dul hatundan otuz akçe alınmaktadır.

h) Tapu-yı żemin ${ }^{51}$ vergisi alınırken fikıh kitaplarında geçen "tahrir sırasında harac-1 mukâseme tahrir olunmuşsa tapu-yı zemîn sâkıt olur" fetvasina göre hareket edilecekir.

48 Resm-i küvvâre (Resm-i kovan): Arıcılık yapan kimselerden arı kovanı mahsulünden alınan bu vergidir. Kânunnâmelerde zenbur resmi ve öşr-i asel olarak da geçmektedir. Bazı yerlerde bal olarak bazı yerlerde para olarak tahsil edilmektedir. $\mathrm{Bu}$ verginin alınma zamanı genellikle harman vakti veya güzündür. Kazıc1, Osmanlilarda Vergi Sistemi, 97-98.

49 Resm-i âsiyâb-1 âb ve bâd ve Resm-i Âsiyâb-1 revgân-1 zeyt : "Osmanlı İmparatorluğunda "değirmen resmi,, "âsiyab resmi, adları altında, su ile veya yel ile dönen un değirmenleriyle zeytin yağ1 değirmenlerinden muhtelif yerlerde ve muhtelif zamanlarda, farklı miktarlarda alınan vergiler kastedilmiştir.” Çağatay, “Osmanlı İmparatorluğu'nda Reayadan Alınan Vergi ve Resimler”, 503.

50 Osmanlı kânunnâmelerinde ve tahrir defterlerinde resm-i arûs, arûsiyye, arûsâne olarak da geçen gerdek resmi, dügün ya da gerdek öncesinde kızın / kadının yakını bir erkek ya da evleneceği erkek tarafindan ödenen bir vergi olmakla birlikte kanunnâmelerde bu konuda bir kesinlik yoktur. Gerdek resminin belirlenmesinde gelin adayının dini durumu (müslim / gayrimüslim oluşu), bakire yada dul oluşu ile babasının malî durumudur. Genellikle gayrimüslim kız / kadınların vergileri Müslüman olanlarınkinin yarısıdır. Aynı şekilde dul kadınlardan alınan vergiler kızlardan alınan vergilerin yarısıdır. Gül Akyılmaz, "Bâd-1 Hevâ Vergilerine Bir Örnek: Resm-i Ârus”, Selcuk Üniversitesi Hukuk Fakültesi Dergisi 7/ 1-2 (Ocak 1999), 115-127. 
1) Bidat-i hınæ̌r ${ }^{52}$ için bir akçe, bir akçe de bojik (domuz kasabı) de kestikleri için olmak üzere toplamda ikişer akçe ödemiş olacaklar.

i) Resm-i gümrïk $k^{53}$ yüz on akçede; Müslümandan iki akçe, yerlü kefere (gayrimüslim tebaa) den dörder akçe, harbî küffar (Osmanlı tebaası olmayan gayrimüslimler) dan beşer akçe alınmaktadır.

j) Cürm ve cinayet ${ }^{54}$ ve bâd ı hevât vergisi ile ilgili olarak "meşru' olmayanlar hakimüll-vakt olanların emrine mevkufdur." ibaresi yer

51 Tapu-yı zemîn: Topraksız köylünün yani kara (mücerered) ve caba-bennakların, sipahi elinde olup tapu ile başkasına verilmemiş toprakları işlemeleri karşllı̆ında dönüm başına ödedikleri paradır. İnalcık, "Osmanlılar'da Raiyyet Rüsûmu”, 592.

52 Bidat-i hınzır: Bidat-i Hinazır veya Canavar resmi olarak da bilinen bu vergi domuz besleyen gayrimüslimlerden alınmaktadır. Sürü halinde beslenen domuzlardan her iki domuz için bir akçe, evde beslenenlerin her birinden 1 akçe olarak tahsil edilirdi. Ünal Taşkın, "Rüsûm-1 Örfiye", Uluslararası Hakemli Disiplinlerarası Tarih Dergisi 14 (İlkbahar-Yaz 2013), 65.

53 Resm-i gümrük: "Devletler arası ticarette sınır geçişlerinde malların kontrol edildiği yer olup bu geçiş sırasında alınan vergilere "gümrük resmi" denmektedir Osmanlı gümrükleri, sahil ve kara gümrükleriyle sınır gümrükleri olmak üzere ayrılmıştı. Kara gümrükleri genelde iç ticaret mallarına uygulanırken sahil gümrükleri hem iç hem dıș ticaret malları için söz konusu oluyordu Ayrıca Müslüman, gayrimüslim ve harbîlerin ödediği gümrük resmi oranları da farklı idi. XVI. yüzylda genellikle Müslümanlardan $\% 3$, gayrimüslim Osmanlı tebaasından $\% 4$, harbîden $\% 5$ oranında resim alınmakla beraber bu oranın farklllık gösterdiği yerler de vardı". Mübahat S. Kütükoğlu, "Gümrük", Türkiye Diyanet Vakfi İslam Ansiklopedisi. (İstanbul: TDV Yayınlar1, 1996), 263-264. Buradaki hesaptan hareketle Müslümandan \% 1.8, Osmanlı vatandaşı olan gayrimüslimden \%3.6, yabancı gayrimüslimden $\% 5.6$ oranında gümrük vergisi alınmaktadır.

54 Cürm ve cinayet resmi: Timar dahilinde yaşayanların işledikleri kabahat ve cinayet üzerine timar sahiplerinin ceza makamında aldıkları para hakkında kullanılan bir tabirdir. Pakalın, "Cürm ve cinayet resmi" 1/ 318. Bu para suçun karşllığ olmayıp suçun cezası kadı tarafından belirlenirdi.

55 Bâd 1 hevâ: "Ne zaman tahakkuk edip tahsil edileceği belli olmayan (zuhurata bağılı bazı resimleri ifade etmek için kullanılmıştır. Ayrıca bunun yerine tahrir defterlerinde aynı anlama gelen Arapça tayyârât kelimesine de rastlanır. Bu vergilerden bazıları: 1. Cürm ü Cinâyet 2. Gerdek Resmi 3. Çiftlik Tapusu.4. Ev Tapusu 5. Tütün veya Duhan Resmi 6. Abd-i Âbık ve Kenîzek Muştuluğu 7. Yava (yitik hayvan) 8. Beytülmâl, Mâl-i Gâib ve Mâl-i Mefkûd 9. Deştibânîdir.” Halil Sahillioğlu, "Bâd-1 Hevâ". Türkiye Diyanet Vakfi İslam Ansiklopedisi. (İstanbul: TDV Yayınları, 1991), 4 / 416-418. 
alırken Beytü'l-mâl, mâl-ı mevkếf ve mâl-ı mefkềd ${ }^{56}$ ve abd-ı âbıkı müjdegânîsi ${ }^{57}$ ile ilgili olarak da "eğer vârisi veya vârisesi biliniyorsa örfî müddet bitinceye kadar marifet-i şer' ile muhafaza edilir. Örfî müddet bittikten sonra hâkimin izniyle dokuz bin dokuz yüz doksan dokuz akçeye kadar beytü'l-mâl-i âmmeye; on binden fazla olduğunda ise beytü'l-mâl-i hâssa olup hazine-i âmireye irsâl oluna gelmişdir. Altı ay geçmeden yâve ciżyesi ${ }^{58}$ talep olunmaz" hükmü yer almaktadır.

k) Zeytin ve palamut bir sene mahsül verip bir sene mahsül vermeyeceği düşünülerek mahsulatın tamamından hums miktarınca iki senede bir vergi alınmasına hükmedilmiştir.

1) Âded-i ağnam ${ }^{59}$ koyun başına ikişer akçedir. Kânun-1 kadim üzere askerîden 150 koyuna kadar vergi alınmaz bundan daha fazla olduğunda

56 Beytü'l-mâl, Mâl-1 Mevkuf (herhangi bir sebeple el konulmuş mal) ve Mâl-1 Mefkûd (kayıp mal): "Mirasçısı bilinmeyen tereke beytülmâlden sayılır; beytülmâl mukâtaası mültezimleri, vâris üç aya kadar ortaya çıkmazsa vasîde tutulan mirasa hazine adına el koyar ve bunu hazineye devrederdi. Ancak mirasçı, tereke beytülmâlci veya hazinede de olsa mirasçılığını ispatladığı takdirde bunu almaya hak kazanırdı. Mirasçı ülke içinde ise tereke mâl-i gâib, mirasçı başka ülkede olup yeri bilinmezse mâl-i mefkûd hükmüne girerdi. Tereke beytülmâlciye bir sene bekletildikten sonra verilirdi. Bu üç çeşit miras hakkında, bulunduğu yere ve tutarının 10.000 akçeden az veya çok olmasına göre işlem yapılırdı." Sahillioğlu, "Bâd-1 Hevâ", 417.

57 Abd-1 Âbık Müjdegânîsi (Muştuluğu): "Kaçan erkek ve kadın kölenin yakalandığ1 sipahi toprağında sahibi gelinceye kadar takdir edilen günlük nafakası ve bunların yakalandığı toprak statüsüne göre iade edilmesi durumunda alınmaktaydı. Kaçan köleyi yakalayan kimse onu sipahisine teslim ettiğinde 20 akçe muştuluk alırdı. Toprağında köle yakalanan sipahiye köle sahibi, bunun bulunduğu yerden gün olarak ifade edilen uzaklığa göre 60 ile 100 akçe olarak takdir edilen muştuluk öderdi. Sipahi yakaladı̆̆ köleyi sahibi gelinceye kadar üç ay saklar ve mahkeme bunun için nafaka takdir ederdi. Sipahi bunu da köle sahibinden alırdı. Bu süre içinde sahibi gelmezse köle satılır ve satış bedeli emaneten saklanırdı.” Sahillioğlu, "Bâd-1 Hevâ", 417.

58 Yâve: Bir tımar arazisinde başıboş olarak tutulan hayvan demektir. Böyle hayvanlar bir ay bekletildikten sonra sahibi çıkmazsa bulanana ait olur ve buna karşllık ondan resm-i yâve veya resm-i kaçkun denilen bir vergi alınırdı. Ünal, "Rüsûm-1 Örfiye", 68-69.

59 Âdet-i ağnâm: Kanunnâmelerde resm-i ganem, olarak geçen bu vergi genellikle koyun yavruladıktan sonra nisan veya mayıs aylarında alınır, kuzulu koyun kuzusu ile bir hesaplanırdı. Vergi miktarı Fatih kanununa göre üç koyundan bir akçe iken daha sonra iki koyundan bir akçe olarak tespit edilmişti. Ancak bu miktar bölgelerin 
alınırdı. Beledî (şehirli) olan Müslümanların resm-i bennak ${ }^{60} l a r ı$ kânun-1 defter mucibince alındığ1 gibi bazen öşür ve diğer vergi bedeli maktu' yani belirlenmiş olanlardan dahi vergi, defter kayttlarına göre alınmaktadır.

m) Zeytin ve diğer meyve ağaçlarının türlerinden sâbib-i arž ${ }^{61}$ için harac-1 hums alınmaktadır.

\subsection{Mehmed Ali Paşa Vakfı İdaresinde Taşoz}

Kavalalı Mehmed Ali Paşa Vehhabi ayaklanmasını bastırdıktan sonra Sultan II. Mahmut'tan, Kavala'da kuracağı külliyenin ihtiyaçlarını karşılamak üzere Taşoz adasının kendisine temlik edilmesini talep etmiş, Sultan II. Mahmud, Mehmed Ali Paşa'nın bu talebini geri çevirmeyerek Taşoz adasını 31 Mart 1813'te kendisine temlik etmiştir. Ada 1813-1902 yılları arasında Misır'dan gönderilen vakıf müdürleri tarafindan idare edilmiştir. ${ }^{62}$

Musa Kâzım Bey Taşoz’un Mehmed Ali Paşa'nın hayatındaki önemine vurgu yaparak başladı̆g 1 makalesinin Taşoz’un Mısırllar Devri başlıklı bu bölümünde Taşoz’un Mısır idaresinde kaldığı süre içerisindeki durumu hakkında şu bilgileri vermektedir:

Özelliklerine göre değişiklik göstermektedir. Kadı, sipahi, müderris, emîn vb. gibi askerî sınıfının 150 koyundan az koyunu olanlarından ağnam resmi alınmazdı. Emecen, Feridun. "Ağnam Resmi”. Türkiye Diyanet Vakfi, İslâm Ansiklopedisi (İstanbul: TDV Yayınlar1, 1988), 1 / 478.

60 Resm-i bennak: Osmanlı vergi sisteminde Müslüman evli erkeklerden alınan şahıs vergisidir. Bennaklar ekinlü (çiftlü) ve caba-bennak olarak ikiye ayrllırdı. Ekinlü bennaklar 4-10 dönümden 24-60 dönüme kadar tasarruf eden reâyâdır. Cababennaklar ise tapu ile tasarruf edeceği toprağı olmayan umumiyetle başkalarının tapulu topraklarında çalışan evli reâyâdır. İnalcık, "Osmanlılar'da Raiyyet Rüsûmu”, 589-590.

61 Kapıkulu ocaklarının süvari kısmını teşkil eden bu ocağın dışında timar tasarruf eden askerî zümrelere de sipahi adı verilir. Bu sonuncuları Osmanlı ordusunun en kalabalık askerî grubunu oluşturur ve dirlik olarak kendilerine verilen arazilerden topladıkları vergiler karşılığında atı ve yardımcısıyla birlikte sefere katılır, "sâhib-i arz" tabiriyle de anilırdı. Erhan Afyoncu, "Sipahi" Türkiye Diyanet Vakfi İslam Ansiklopedisi, (İstanbul: TDV Yayınlan1, 2009), 37/ 256.

62 Kiziltoprak, "Taşoz”, 160. 
Kavala'da doğan ve hayatını türlü mücadeleler ile geçiren 17-18 yaşlarında düşmanları tarafından takip edilen Mehmed Ali, canını kurtarmak için Taşoz'a sığınmış ada halkı onu saklayıp himaye etmiştir. Taşoz'da saklandığını anlayan düşmanları onu köy köy aramışlar ancak ada halkından onu almayı başaramamışlardır. Aramaların sürdüğü sırada Theologos köyünde bir adamın kılavuzluğu ve köye ait kayık ile Enus'a kaçırılmıştır. H.1216 / M. 1801 y1lında Mısır'a giderek oraya vali olmuştur.

Mehmed Ali Paşa, Taşoz varidatlarının Kavala'daki imaretleri için kendisine tahsis edilmesini Sultan Mahmut'tan talep etmiştir. ${ }^{63}$ Taşoz adası, aşağıda verilen ferman suretinde görüldüğü üzere, padişah tarafindan kendisine ihsan edilmiştir. H.1253 / M.1837 senesinde Taşoz'un varidâtı Sirozlu İsmail Paşa'dan alınarak Kavala'daki Mehmed Ali Paşa'nın vakıflarına tahsis edilmişse de Bab-1 Âli ile Mehmed Ali Paşa arasındaki sorunlardan dolayı, Taşoz'un varidatları ancak H.1260 / M. 1844 yılında Kavalalı Mehmed Ali Paşa’nın vakıflarına bağlanabilmiştir.

Mehmed Ali Paşa H. 1262 / M. 1844 yılında İstanbul'a gelirken Kavala'ya uğrayıp daha sonra Taşoz'a geçmiş vaktiyle kendisine yardım eden Hiristiyanlara teşekkür ederek ihsanlarda bulunmuş ve ada halkı tarafindan çok parlak bir merasimle uğurlanmıştır. Dönüşü sırasında adanın gümrüklerini de vakıf gelirlerine ilhak ettirmiştir. H.1268 / M.1851 y1lında Bab-1 Âli, Taşoz gümrüklerinden sarf-1 nazar etmiş bu durum Duyûn-1 Umûmiye'nin teşkiline kadar devam etmiştir.

Musa Kâzım Bey, Mehmed Ali Paşa'nın Kavala'daki vakıf eserlerinin masraflarının karşılanması için yapılan bu "vakfiyete" tasarruf manası da yüklenerek Taşoz'un altmış sekiz sene Mısır idaresinin mülkiyetinde kaldığını belirtmektedir. Musa Kâzım Bey, Taşoz adasının Mısır idaresi altında kaldığı bu sürenin tam bir karışıklık dönemi olduğuna vurgu yapmakta ve bunun sebebini aşağıdaki tabloda isimleri geçen müdürlerin büyük bir kısmının tecrübesiz oluşlarına ve adanın idâre-i kadîmesini (geleneksel idaresi) devam ettirememelerine

63 Musa Kazım Bey, makalesinde Mehmed Ali Paşa'nın, Sultan II. Mahmud'dan Kavala'daki imaretlerinin masraflarını karşılamak için Taşoz'un kendisine temlik edilmesini talep ettiğini yazmaktadır. Ancak fermanda Mehmed Ali Paşa'nın Taşoz'un varidatını, Mısır'da yaptıracağı câmi için talep ettiği kayıtlıdır. 
bağlamaktadır. Ayrıca müellif ada halkının memnuniyetsizliğine sebep olan bu durumun peş peşe gelen birçok kargaşaya da sebep olduğunu ilave etmektedir.

\section{İstanbul Kapı Kethüdalığından ${ }^{64}$ Tayin Olunan Müdürler}

\begin{tabular}{|c|l|l|}
\hline Sıra & \multicolumn{1}{|c|}{ İsim } & \multicolumn{1}{|c|}{ Görev Süresi } \\
\hline 1 & Liman Ağa & $1253(1837)$ \\
\hline 2 & Süleyman Bey & $1253-1260(1837-1844)$ \\
\hline 3 & Hafiz Efendi & $1260-1266(1844-1849)$ \\
\hline 4 & Salih Bey & $1266-1269(1849-1852)$ \\
\hline 5 & Sinan Bey & $1269-1272(1852-1855)$ \\
\hline
\end{tabular}

Mısır Evkaf Nezaretinden Gönderilen Müdürler

\begin{tabular}{|c|l|c|}
\hline S1ra & \multicolumn{1}{|c|}{ İsim } & \multicolumn{1}{c|}{ Görev Süresi } \\
\hline 1 & Cafer Paşa & $1272-1280(1855-1863)$ \\
\hline 2 & Mehmed Liva Paşa & $1280-1288(1863-1871)$ \\
\hline 3 & İbrahim Edhem Bey & $1288-1290(1871-1873)$ \\
\hline 4 & İbrahim Asefî & $1290-1298(1873-1880)$ \\
\hline 5 & Tosun Bey & $1298-1301(1880-1883)$ \\
\hline 6 & $\begin{array}{l}\text { (̇́kinci defa) İbrahim Asefî } \\
\text { Bey }\end{array}$ & $1301-1303(1883-1885)$ \\
\hline 7 & Mustafa Ibadî Bey & $1303-1306(1885-1888)$ \\
\hline
\end{tabular}

64 Kapı Kethüdası: Osmanlı Devleti'nde taşrada görevli vezir rütbeli memurların, merkezle gerek resmi gerekse özel yazışmalarını takip etmek üzere başkent ( İstanbul)te bulunan adamlarıdır. Döndü Düşünmez, "Tanzimat Devrinde Kap1 Kethüdalığ1 Müessesesi Hakkında Temel Bilgiler”, Selcuk Üniversitesi Türkiyat Arasstormalar Dergisi, 28 (Aralık 2010), 378-379. Burada İstanbul Kap1 Kethüdalığından maksat İstanbul'daki Mısır Hidivliğine ait Kap1 Kethüdalığıdır. 


\begin{tabular}{|c|l|l|}
\hline 8 & Mustafa Sadık Bey & $1306(1888)$ \\
\hline 9 & Fehim Bey & $1306-1312(1888-1894)$ \\
\hline 10 & Hamdi Bey & $1312-1313(1894-1895)$ \\
\hline 11 & İshak Bey & $1313-1315(1895-1897)$ \\
\hline 12 & Halil Efendi ( vekaleten) & $1315-1317(1897-1899)$ \\
13 & Zeki Efendi (vekaleten) & $1317-1318(1899-$ \\
\hline 14 & Mahmud Rifat Bey & $1900 / 1901)$ \\
\hline
\end{tabular}

Musa Kâzım Bey, Taşoz adasında idarede yazılı olmayan bazı ananelerin olduğunu belirtmektedir. Buna göre Roma eski idare usulüne uygun olarak ada, bir bas çorbacı, her köy için bir çorbacı, bir kocabaşı ile Müslüman bir subaşı tarafından idare olunmaktaydı. Adanın idaresi heyeti umumiye itibariyle bir tür bağımsızlı̆̆a sahipti. Baş çorbacı hükûmet ile ada halkı arasında haberleşme vasıtasıydı. Her sene köyleri gezen baş çorbacı gittiği köylerde köyün ileri gelenleriyle bir meclis kurar ve başkan sıfatıyla en mühim meseleleri bile çözüme kavuştururdu. Musa Kâzım Bey, baş çorbacılardan Ağunanuset Akünüm, Haci Yorgi Yanaki, Haci Sitamati ve Dimitri Haci Konstantin'in şanının hâlâ devam ettiğini söylemektedir. Bundan başka çorbacilar ikinci derecede olan idare ve adliye işlerine bakarken kocabaşılar maktu' ve gayr-i maktu' vergilerin tahsilatına; subaşılar ada ve köy meclislerinin aldığı kararları icraya, ekili arazilerin korunmasina zarar ve ziyanların tazminine nezaret ederlerdi. Baş çorbacı, çorbacı, kocabaşı ve subaşının maaşları halk tarafindan ödenmekteydi.

Musa Kâzım Bey Taşoz adasından alınan vergilerle ilgili olarak şu bilgilere yer vermektedir:

a) Zeytin ve zeytinyağından öşür alınmaktadır ki zeytinin öşrü hiçbir zaman 8000 lirayı geçmemiştir.

b) Her bir koyun ve keçiden 2 para,

c) Arı kovanlarından 6 para, 
ç) On iki kıyyelik hububattan 10 para,

d) Her bir yayladan 120 para, her ksşlaktan 22 para,

e) Her bir değirmenden 22 para,

f) Dükkan ve diğer müsakkafattan 200 para,

g) Katran ocaklarindan 22 para,

h) Bir çift öküzden 110 para,

1) Her bir yabancı balık ağ1 ile hızardan 150 'şer para vergi alınmaktadır.

Adanin 5625 kuruş cizye ve 5000 kuruş bal mumu vergisi maktudur. Mart ve Eylül vergileri 13028 kuruş olup adanın yıllık vergisi 74278 kuruşa ulaşmaktadır. Vergilerin mart taksitine Martiya eylül taksitine İspenc denilmektedir.

Musa Kâzım Bey, bidivlerden ${ }^{65}$ övgüyle söz etmektedir. Mehmed Ali Paşa'dan sonra Misır'a hidiv olanlar Taşozlulara karşı oldukça hoşgörülü ve cömert davranmışlardır. Tevliyeti sebebiyle Taşoz’un madenlerine nezaret eden ve o sıralarda henüz çıkarılmaya başlanan çinko madeninin fermanını alan Prens Halim Paşa adanın huzur ve rahatına son derece dikkat ve itina etmiştir. Nitekim H. 1307 / M. 1889 yılında yeni vergiler koyarak adada isyanın çıkmasına sebep olan imaretin nazırı Hasan Efendi, Prens Halim Paşa'nın onayıyla ebediyen memuriyetten uzaklaştırılmıştır. Aynı şekilde Hidiv Said ve İsmail Paşaların ada için yaptıkları da zikredilmeye layıktır. Nitekim H.1291 / M. 1874 senesinde yaşanan kuraklık sırasında İsmail Paşa Taşoz'a vapurla meccanen zâhire yine o esnada ortaya çıkan çiçek hastalığının tedavisi için de heyet-i sıhhiye göndermiştir.

Ada sakinleri hidivlerden memnun olduklar1 kadar Misır'dan gönderilen vakıf memurlarından ise memnun kalmamışlardır. H.1250 / M. 1834 yilından H.1272 / M.1855 yılına kadar adanın işleri adalet ve hakkaniyet üzere yürütülmüştür. H. 1273 / 1856 senesinin başlarında ada halkını rahatsız eden bir olay yaşanmıştır. Şöyle ki bir eşkıya grubu

65 Hidiv, kelime olarak vezir anlamina gelmekte olup, 1867 y1lından sonra Osmanlı idaresindeki Mısır valilerine verilen unvandır. 
Dedeağaç'a bağlı Acı Su sahilinde bir Fransız gemisini yakmış, içindeki malları gasp ettikten sonra Taşoz dağlarına çekilmiştir. Adanın yöneticisi durumunda olan Misrî Sinan Bey -Selanik vilayetinin emri gereğinceadanın önde gelen isimlerini Selanik vilayetine göndermiştir. Adanın önde gelenlerinin Selanik'e gönderilmesi ada halkını son derece kızdırmış bu duruma isyan eden ada halkı, Hidiv Said Paşa nezdine bir şikayet heyeti göndermiş ve Dersaadet Kethüdasının (İstanbul'daki Mısır Hidivliği Kap1 Kethüdası) Nezaretinden ayrilarak doğrudan Misır'a bağlanmayı istirham etmişlerdir.

Musa Kâzım Bey, “ada halkının İstanbul Misır Hidivliği Kap1 Kethüdalı̆̆ından ayrilıp doğrudan Misır Evkaf Nezaretine bağlanma taleplerinin kendilerini başka felaketlere sürükleyeceğini bilemediler" diyerek bunun sebebini şöyle izah etmektedir: Ada halkının Misır Evkaf Nezaretine bağlanma talebinin ardından H. 1272 / M.1855 yllının sonlarında Cafer Paşa geniş bir yetki ile Taşoz vakıf müdürlüğüne tayin olmuş, Cafer Paşa bir yandan yeni muavinler, katipler, tercümanlar istihdam ederken diğer yandan alınmakta olan vergilerin miktarını artırmaya teşebbüs etmiştir. H.1285 / M.1868 yılında Müdür Mehmed Liva Paşa Kurra İanesi adıyla adanın ithalat ve ihracatına daha önce olmayan bir vergi koymuştur. H. 1303 / M.1885 y1lında Müdür Mustafa İbadî Bey ise dört senede bir kere adadan ihraç olunan çam kabuğunun her bir kiyyesinden birer para vergi almış, halka alınan bu verginin yol, köprü, geçit vd. inşaatına harcanacağını duyurmuş ancak alınan bu paralar söz edilen inşaatlar yerine imaret sandığına mâl edilmiştir.

Musa Kâzım Bey, Mısır Evkaf müdürlerinin hidivlerin istekleri ve niyetleri yönünde hareket etmeleri gerekirken, idarelerini te'dib ve intikam üzerine kurduklarını belirtmekte olup müdürlerin kanunlara aykırı davranışları ile ilgili olarak, "1284 yılında baş çorbacilığı lağvederek görevlerini bir meclis-i umumiye verdiler. 1304 yıllnda çorbacılara muhtar, kocabaşılara aza ve subaşılara muhafız denildi. Yerli halktan olan jandarmalara izin verilerek yerlerine Mat kazasindan adamlar getirildi. Mısırlılardan süvari jandarması yazdırıldı ve bunların hayvanları köylülere besletildi" demektedir.

1292 senesinde kurulan eytambâne ve cüzzambâneler nizamlarına uyulmadığ1 gibi mektep afuryalar (maarif encümenleri)nın adadaki çalışmalarına da mani olunmuştur. Ayrıca 1305 yılında meclis-i umumi (genel meclis) usulü terk olunarak merkez livada bir idare meclisi ile 
adliye mahkemeleri açılmıştır. Ancak merkezde açılan bu meclis ve mahkemelere gidip gelmek halk için oldukça zahmetli olmuştur.

Taşoz’un Misır Evkaf Nezaretine bağlı müdürler tarafindan idare edildiği dönemde halkın aleyhine bir gelişme de ekonomik hayatta yaşanmıştır. Şöyle ki daha önce ormanlardan öşür bile alınmazken 1315 yllinda imaretler hesabina bitirme adiyla \%30; ormaniye namiyla \%24; gümrük hakk1 ve kurra iânesi olarak \% 12; toplamda \%66 oranında bir verginin tahsiline başlanmış bu vergiler zinciri halkı çıldırtmıştır.

Özellikle ormaniye vergisi halkı çok rahatsız etmiştir. Çünkü Prens Halim Paşa, izinsiz kesime izin vermişti. Orman vergileri yüzünden baş gösteren kargaşa adanın yöneticilerinde herhangi bir uyanışa vesile olmamış, 1316 yılında nüfus, arazi ve emlak tahririne başlanmıştır.

Adanın yöneticileri yeni vergiler koymalarının yanı sıra bir de mevcut vergileri arttırmıştır. Daha önce 2 para olan ağnam vergisi 10 paraya; kovan resmi 6 paradan 12 paraya çıkmıştır. Müskirât (şarap), sayd-ı berrî (kara avc1lığı), sayd-ı bahrî (deniz, göl, nehir avcıllğı), taş ocakları vergileriyle tütün ve orman öşürlerinin toplanması için tahsildarlara defterler dağıtılmıştır.

Ekonomik alanda yapılan bu baskılar Ada halkını gergin ve yöneticilere karşı öfkeli hale getirmiştir. Müdüriyete dilekçe gönderilmesi, izinsiz toplanılması yasaklanmıştır. Bu yasağa uyulup uyulmadığını kontrol için zabıta memurlarından Hurşid ve Hilmi ve müdür muavinlerinden Yani ve Kolonay Efendiler teftişe çıkmış, şikayetlerini dile getirmek için mutasarrıflık dairesine gelen halktan büyük bir grup, sopa ile köylerine gönderilmişlerdir.

Bütün bu haksızlık, bask1 ve zulme daha fazla dayanamayan halk 9 Haziran 1317 ( 22 Haziran 1901) tarihinde Panaya Kilisesi avlusunda bir miting yapmış ölmek ve öldürmek üzerine karar almıslardır. İdareye karş1 ayaklanan halktan bu grup üç gün boyunca çan çalmıştır. Musa Kâzım Bey bu çan seslerinin büyük bir korkuya sebep olduğunu "ortalığ1 büyük bir korku istila etti, çan sesinin korkusundan köydeki hayvanlar meralarından inemez oldu" şeklinde aktarmaktadır.

İsyanc1 grup baskı ve zulmün durdurulması için İstanbul, Misır ve Selanik'e telgraflar çekmişlerdir. Durumdan haberdar olan Misır Hidivi II. Abbas Hilmi Paşa, ada sakinlerine yapılan kötülüklerin ve zulmün kaldırılması yönündeki emirnâmesini halka duyurmak üzere Mısır 
müdürü askerî kaymakamlarından Mahmud Rıfat Bey’i görevlendirmiştir. Ancak Mahmud Rifat Bey'in bizzat kendisinin sebep olduğu bir hadise emirnamenin okunması bir yana daha büyük bir öfkeye ve galeyana sebep olmuştur. Musa Kâzım Bey'in aktardığına göre Mahmud Rifat Bey, Potamya adlı köyden geçerken Mariyes köyünden bir kadını bostanından zorla çıkartması ve onu dövmesi halkı galeyana getirmiştir. Musa Kâzım Bey'e göre Taşoz'un Misır Hidivliğinden ayrilmasına bu olay sebep olmuştur. Ona göre Taşoz'daki isyanları organize eden ve kargaşanın kesintisiz olarak devamını sağlayanlar tıpçlardan Yanyalı Hıristidi, yerli halktan Doktor Dimitriyadi ile belediye reisi Antonyadi Efendilerdir.

Taşoz adasındaki halk isyanları nihayet netice vermiş Sadrazam Said Paşa'nın kesin emri ve Selanik Valisi Hasan Fehmi Paşa'nın gayretlerinin ürünü olarak Kavala kaymakamı Sakızlı Emin Paşa 9 Haziran 1317 tarihinde 180 nefer nizamiye ve 45 jandarma ile Taşoz sahiline çıkmış ve ahaliden büyük bir hüsn-i kabul görmüştür. Sevkiyat memuru olarak Menlikli Hüseyin Bey ve Giridli Ziya Bey görev almıştır.

Musa Kâzım Bey, Taşoz'un Misır Hidiviyetinden ayrılmasından sonra gâh mutasarrıflık gâh kaza olarak Selanik vilayetine bağlı olarak doğrudan Hükumet-i seniyye (Osmanlı hükumeti ) idaresine geçtiğini belirtmektedir.

\subsubsection{Sultan II. Mahmud'un Fermanı}

Musa Kâzım Bey'in makalesinin sonunda Sultan II. Mahmud'un Taşoz adasını Mehmed Ali Paşa'ya temlik ettiğini gösteren ferman bulunmaktadır. 27 Rebiülevvel 1228 (30 Mart 1813) yllına ait bu ferman aynı zamanda bir mülknâmedir. Fermanda şu bilgiler yer almaktadır:

Mısır Valisi Vezir Mehmed Ali Paşa, vilayetine bir câmi yaptırmak isteğini ve bu câminin vakfinın giderlerinin karşılanması için Taşoz adasının kendisine temlik edilmesi talebini kapı kethüdasına iletmiştir. Hazine-i Âmire defterlerine bakılarak adanın o sıradaki durumu incelenmiştir. Taşoz ve kendisine bağlı olan yerler, dört yük elli bin akçe mal ile Kaptanpaşa hassı iken 1153 / 1740 yllında Sultan I. Mahmud'un kütüphanesi, imareti ve diğer vakıflarına tahsis edilmiş daha sonra evkâf mukâtaat1; mukâtaat-1 mîriye gibi mal ve kalemiye takdir olunarak Haremeyn-i muhteremeyn evkafina kaydolunmuştur. 1173 /1759-1760 yllında hatt-1 hümayunla adadan alınan cizye de mukataa kapsamına 
alınmış bu tarihten itibaren bu mukataa, malikâne olarak kayıttan kayda geçmiştir.

$\mathrm{Bu}$ fermanın irad edildiği sırada Taşoz vâridatı yıllık yirmi bin altı yüz yetmiş sekiz kuruş mal ve dokuz yüz yirmi beş kuruş muaccele ile malikane olarak Drama Nazırı Mahmud Bey ile diğer ortaklarının üzerindedir.

Adanın cizye geliri esnâf-ı selâse üzere bin iki yüz otuz altı evrak ve yedi bin altı yüz doksan yedi buçuk kuruş mal olarak kaydedilmiştir. Bu meblağın altı bin dört yüz yetmiş beş kuruşu Tersane-i Âmire Hazinesi’ne ve kalanı mevâcibe (maaşlara) ayrılmıştır. Adadan kalyoncu bedeliyesi olarak yıllık beş bin kuruş tahsil edildiğinden başka tersane için gerekli kerestelerin nakli de yapılmaktadır.

Bir buçuk rubu' ve sülüs hissesi müteveffâ Sadrazam Mehmed Paşa'nın uhdesinde olan Maraş sancağına bağlı Elbistan nahiyesinin mukataasından ber vech-i has olmak üzere her sene yüz kuruş vakfın mütevellisi eliyle Hazine-i Amire'ye teslim edilecektir. Bu yüz kuruşluk gelir hatt-1 hümayun ile Mehmed Ali Paşa'nın vakfina ilhak edilmiştir.

Mehmed Ali Paşa'nın kapı kethüdası Necip Efendi, Paşa adına daha önce adanın mukataası üzerinde tasarruf hakkı olanların hakkını ödeyebileceklerini bildirmiştir. Ayrıca Tersane-i Âmire'ye verilen mal, kalemiye ve kalyoncu bedeliyesi ödeme vakti geldiğinde ödeneceği yine ihtiyaç duyulan kerestenin nakl olunacağı, adanın cizye gelirinin ise eskiden olduğu gibi mukataaya bağlı olacağı beyan edilmiştir.

Mehmed Ali Paşa'nın Taşoz'un kendisine temliki karşllı̆ı̆nda daha önceki tasarruf sahibi kimselerin haklarını bu şekilde ödeme talebi üzerine Sultan II. Mahmud fermanındaki “... müsâru ileyhe temlikeen ihsân-ı Hümâyûnum olduğu balde gayr-ı eq-mâl ve kalemiye muayyen olan fâiż mukâbili mutasarnflarma ol mikedâr fâiz̨li sehm-i kavâimi tedârik ve i'tâ ve isterler ise fâizine göre iktizâ eden muaccelesi nakden te'diye olunacağım ve bazâin-i sülïse-i merkêmeye senevî müretteb ve muayyen olan mal u kalemiye ve kalyoncu bedeliyesi her ne ise be-her sene vakt ü zamânyle edâ ve teslìm ve lede'l-iktizâ kerâste matluib olunursa tanzîm ve cizyesi dabi kemâ fi's-sâbık. mukâta'a-i mezbûreye merbûten edâ kıllnacağın ifâde eylediği ba-takrîr rikâb-ı Hümâyûnuma arz ve takdìm olundukeda bu adamm din ü devlete eyledigi hidmet ve mâlen ve bedenen gayret ve hamiyyeti birkaç Taşoz verilse yine ivâz. değildir." sözleriyle geri çevirmiştir. 
Padişah, Mehmed Ali Paşa'nın Hicaz'da Vehhabileri dize getirmesi bölgede huzuru sağlamasındaki başarısı karşısında Taşoz'un kendisine temlikin az bile olduğunu "... Hicaz mesâlibinde sarf eylediği akşe buna bin kere muaccele olabilir müşâru ileyh Mehmed Ali Pașa kulum ashâb-ı mâlikânemin verdiği muacceleyi veririm demis ise de ben almağa bicâp ederim ashâb-ı mukâta'ay düsen mablulât-ı mukâta'a ve gerek eshâm ile iskât idüp tersâne mürettebâtı ve gerek kerâste ve kalyoncu bedeliyesi vesâir tekâlifden cis̀yeden mâadâsı afv olunsun müsâäü ileybin eylediği hidmeti kimseler etmedi cümleniz, buna teslim olursuг..." cümleleriyle dile getirmektedir. Sultan II. Mahmud, fermanında cizyenin haricindeki tersâne mürettebâtı ve kerâste ve kalyoncu bedeliyesi ve sâir tekâlif ve mâl-ı mukayyedi muaccele ödemeksizin Mehmed Ali Paşa'ya temlik etmiştir.

\section{SONUÇ}

Taşoz, Ege Denizi’ndeki adalar içerisinde karaya özellikle de Balkanlara yakın olması bakımından stratejik önemi olan bir adadır.

Musa Kâzım Bey, kaleme aldığı makalesinde Taşoz’un coğrafî özellikleri üzerinde sınırlı bilgi bilgiler verirken adanın tarihi hakkında detaylı bilgiler vermektedir. Taşoz'un tarihi hakkındaki bilgileri milattan önceki dönemden başlatan Musa Kâzım Bey, Osmanlı idaresine girdikten sonraki süreci daha geniş ele almaktadır.

Musa Kâzım Bey’in tarihçi kimliği ada hakkında verdiği bilgileri ilmî anlamda değerli kılmaktadır. Müellifin kısa süre de olsa Taşoz mutasarrıfllğ 1 vazifesinde bulunmuş olması adayı yakından tanımasına firsat vermiştir. Gerek adanın mutasarrıfllğını yürüttüğü dönem gerek içinde yaşadığ1 yüzyıl içinde adanın durumu hakkında verdiği bilgiler birincil kaynak niteliği taşımaktadır.

Musa Kâzım Bey'in makalesi adanın Mısır vakıf idaresine geçmesinden önceki ve sonraki dönemdeki yönetimi, yöneticilerin isimleri ve görevleri hakkında bilgi vermesi bakımından önemlidir. Bundan başka Mısır vakıf idaresinin hâkim olduğu dönemde adadan alınan vergiler hakkında verdiği bilgiler de önem arz etmektedir.

Musa Kâzım Bey'in makalesinde yer alan kânunnâme, Taşoz'un sosyal, kültürel ve ekonomik hayatı hakkında bilgiler vermesinin yanı sıra Osmanlı Devleti’ne bağlı gayrimüslim tebaadan alınan vergilere ış1k tutmaktadir. 
Makalede yer alan ve Taşoz'un Sultan II. Mahmud tarafindan Mehmed Ali Paşa'ya temlik edildiğini konu alan ferman, Taşoz tarihi ve vakıf tarihi açısından önem taşımaktadır. Nitekim fermanda adanın sadece gelirleri vakfedilmişken, vakfin gelirlerine nezaret etmekle görevli vakıf müdürlerinin adanın idaresinde nasıl etkili oldukları ve daha sonrasında yaşanan sorunlar Musa Kâzım Bey tarafından belirtilmiştir. 


\section{KAYNAKÇA}

\section{Arşiv Kaynakları}

BOA. Osmanlı Arşivi. Maarif Nezareti-Mektubi Kalemi [MF.(MKT)]. No. 189,Gömlek No. 42.

BOA. Osmanlı Arşivi. Maarif Neqareti-Mektubi Kalemi [MF.(MKT)]. No. 244, Gömlek No. 18.

BOA. Osmanlı Arşivi. Maarif Nezareti-Mektubi Kalemi [MF.(MKT)]. No. 330, Gömlek No. 42.

BOA. Osmanlı Arşivi. Maarif Nezareti-Mektubi Kalemi [MF.(MKT)]. No. 296, Gömlek No. 46.

BOA. Osmanlı Arşivi. Maarif Nezareti-Mektubi Kalemi [MF.(MKT)]. No. 321, Gömlek No.8.

BOA. Osmanlı Arşivi. Maarif Nezareti-Mektubi Kalemi [MF.(MKT)]. No. 244, Gömlek No. 18.

BOA. Osmanlı Arşivi. Maarif Nezareti-Mektubi Kalemi [MF.(MKT)]. No. 330, Gömlek No. 42.

BOA. Osmanlı Arşivi. Dabiliye- Mektubi Kalemi [D.(MKT)]. No. 532, Gömlek No. 20.

BOA. Osmanlı Arşivi. Dabiliye- Mektubi Kalemi [D.(MKT)]. No. 2606, Gömlek No.137.

BOA. Osmanlı Arşivi. Dabiliye- Mektubi Kalemi [D.(MKT)]. No. 2786, Gömlek No.16.

BOA. Osmanlı Arşivi. Yıldız- Maruzat Defterleri [Y.(MRZ)]. No. 10475.

BOA. Osmanlı Arşivi. Dabiliye- Mektubi Kalemi [D.(MKT)]. No. 1182, Gömlek No. 60.

BOA. Osmanlı Arşivi. Yuldı̨-Resmi Maruzat Defterleri [Y.(RES)]. No.120, Gömlek No. 94.

BOA. Osmanlı Arşivi. Bab-ı Ali Evrak Odası [BEO.]. No.2969, Gömlek No. 222647.

BOA. Osmanlı Arşivi. Yoldız-Hususi Maruzat Defterleri [Y.(HUS.)]. No.514, Gömlek No.105. 


\section{Diğer Kaynaklar}

Afyoncu, Erhan. "Sipahi”. Türkiye Diyanet Vakfi İslâm Ansiklopedisi. 37/ 256-258. İstanbul: TDV Yayinlar1, 2009.

Akgündüz, Ahmet. Osmanl Kanunnâmeleri ve Hukuki Tablilleri. 10. Cilt. İstanbul: Osmanlı Araştırmaları Vakfı Yayınları, 2015.

Akyılmaz, Gül. "Bâd-1 Hevâ Vergilerine Bir Örnek: Resm-i Ârus". Selçuk Üniversitesi Hukuk Fakültesi Dergisi 7/ 1-2 (Ocak 1999), 115-128.

Akyüz, Yahya. Türk Eğitim Taribi. İstanbul: İstanbul Kültür Üniversitesi Yayınları, 6. Baskı, 1997.

Arslan, Ali. Balkeanlarm Anabtarn Önemi Bilinmeyen Ada: Taşöz. İstanbul: Emre Yayınları, 1. Basım, 2005.

Binbaşığlu, Cavit. Başlangıçtan Günümüze Türk Eğitim Taribi. Ankara: Anı Yayınlar1, 2009.

Binbaşığlu, Cavit. 'Türkiye'de Eğitim Bilimleri Tarihi Araştırmaları: II. Meşrutiyet Döneminden Harf Devrimine Kadar Öğretmen Okullarında Okutulan Eğitim Bilimine İlişkin Kitaplar”. G.Ü. Gazi Eğitim Fakültesi Dergisi 16 /2 (1996), 101-113.

Çağatay, Neşet. "Osmanlı İmparatorluğu'nda Reayadan Alınan Vergi ve Resimler". Ankara Üniversitesi Dil ve Tarih-Coğrafya Fakültesi Dergisi 5/5 (1947), 483-511.

Demircan, Yasemin. Osmanl İdaresinde Taşoz: Ankara: TDFO, 1996.

Düşünmez, Döndü. “Tanzimat Devrinde Kap1 Kethüdalığ1 Müessesesi Hakkında Temel Bilgiler". Selcuk Üniversitesi Türkiyat Arastırmalar Dergisi 28 (Aralik 2010), 375-401.

Emecen, Feridun. "Ağnam Resmi”. Türkiye Diyanet Vakefi İslâm Ansiklopedisi. 1/ 478-479. İstanbul: TDV Yayınları, 1988.

Emecen, Feridun. "Para". Türkiye Diyanet Vakefı İslâm Ansiklopedisi. 34/ 166-167. İstanbul: TDV Yayınları, 2007.

Ercan, Yavuz. “Osmanlı İmparatorluğu'nda Gayrimüslimlerin Ödedikleri Vergiler ve Bu Vergilerin Doğurduğu Sosyal Sonuçlar". Belleten 55/ 213 (Ağustos 1991), 372-391. 
Erden, Elif. Yakın Dönem Taribimizde Tassoz. Adası. İstanbul: İstanbul Üniversitesi, Sosyal Bilimler Enstitüsü, Yüksek Lisans Tezi, 2004.

Göçeri, Nebahat. 'Kozan Mutasarrıf-1 Esbakı Musa Kâzım'ın Kitaplar1I". Cukurova Üniversitesi Türkoloji Dergisi 3/2 ( Aralık 2018), 95119.

Göçeri, Nebahat. 'Kozan Mutasarrıf-1 Esbak1 Musa Kâzım'ın MakalaleriII”. Çukurova Üniversitesi Türkoloji Dergisi 3/2 (Aralık 2018), 120130.

Gürer, Ahmet Şamil. Gelenekle Modernite Arasinda Bir Meşrûtiyet Seybülislâmı: Musa Kâzım Efendi (1861-1920). Ankara: Hacettepe Üniversitesi, Sosyal Bilimler Enstitüsü, Doktora Tezi, 2003.

Halil Edhem, Fibrist-i Umumi. İstanbul: Devlet Matbaası, 1928.

İnalc1k, Halil. “Osmanlılar'da Raiyyet Rüsûmu”. Belleten 23/92 ( Ekim 1959), 575-610.

İnalcık, Halil. Osmanlı İmparatorluğu Klâsike Çăg (1300-1600). İstanbul: Yap1 Kredi Yayınları, 4. Basım, 2004.

Karakaş, Nuri. "Lozan Konferansı Görüşmelerinde Ege Adaları". Ege Adalarmm Unutulan Halk: Rodos ve Istanköy Türkleri. ed. Mustafa Kaymakçı, Cihan Özgün. 235-251. Konya: Eğitim Yayınevi, 1. Basım, 2019.

Kazıc1, Ziya. Osmanllarda Vergi Sistemi. İstanbul: Şamil Yayınevi, 1977.

Kuz1ltoprak, Süleyman. "Taşoz” . Türkiye Diyanet Vakfi İslâm Ansiklopedisi. 40/ 159-161. İstanbul: TDV Yayınları, 2011.

Kiel, Machıel. "Selânik". Türkiye Diyanet Vakfı İslâm Ansiklopedisi. 36/ 352-357. İstanbul: TDV Yayınlar1, 2009.

Kütükoğlu, Mübahat S. "Gümrük". Türkiye Diyanet Vakfi İslâm Ansiklopedisi. 14 / 263-268. İstanbul: TDV Yayınları, 1996.

Musa Kâzım. "Taşoz Tarihçesi”. Tarih-i Osmani Encümeni Mecmuası (TOEM) 4/20 (1 Haziran 1329), 1260-1262.

Özcan, Abdülkadir. "Târih-i Osmânî Encümeni”. Türkiye Diyanet Vakft İslâm Ansiklopedisi. 40/ 83-86. İstanbul: TDV Yayınlar1, 2011. 
Pakalın, Mehmet Zeki. Osmanl Tarih Deyimleri ve Terimleri Sǫ̈lügü̈. İstanbul: Milli Eğitim Bakanlığ1 Yayınları, I. Cilt, 1993.

Pakalın, Mehmet Zeki. Osmanl Tarih Deyimleri ve Terimleri Söəlüğ̈̈. İstanbul: Milli Eğitim Bakanlığ1 Yayınları, II. Cilt, 1993.

Parmaksızoğlu, İsmet. "Mûsa Kâzım Efendi”, Türk Ansiklopedisi. 24/457458. Ankara: Milli Eğitim Basımevi, 1976.

Sahillioğlu, Halil. "Bâd-1 Hevâ". Türkiye Diyanet Vakfi İslâm Ansiklopedisi. 4/ 416-418. İstanbul: TDV Yayınları, 1991.

Selânik Vilâyeti Salnâmesi (1322). Selanik: Hamidiye Mekteb-i Sanayi Matbaas1. 1322.

Şakiroğlu, Mahmut H. "Cezâyir-i Bahr-i Sefîd ”. Türkiye Diyanet Vakfı İslâm Ansiklopedisi. 7 / 500-501. İstanbul: TDV Yayınları, 2011.

Şanal, Mustafa. "Musa Kâzım Bey’in (1858-1919) Türk Eğitim Tarihindeki Yeri ve Öğretmenlik Mesleğine İlişkin Görüşleri". Turkish Studies 5/3 (Summer 2010), 1860-1879.

Tarib-i Osmanî Encümeni Mecmuası. "İfade-i Meram” 1/1 (1 Nisan 1326), $1-3$.

Tarih-i Osmanı̂ Encümeni Mecmuası. "Tarih-i Osmanî Encümeni Hakkında Talimat Sureti” 1/1 (1 Nisan 1326), 4-8.

Taşkın, Ünal. "Rüsûm-1 Örfiye". Uluslararası Hakemli Disiplinlerarası Tarih Dergisi 14 (İlkbahar- Yaz 2013), 55-73.

http://www.izmit.gov.tr/izmit-saat-kulesi 